\title{
Skuteczność i koszty leczenia raka odbytnicy w Polsce; podejście regionalne
}

\author{
Adam Kozierkiewicz ${ }^{1}$, Roman Topór-Mądry², Anna Kowalczyk ${ }^{3}$, \\ Dariusz Gilewski ${ }^{4}$, Andrzej Śliwczyński ${ }^{5}$, Tadeusz Jędrzejczyk ${ }^{5}$, Jacek Jassem ${ }^{3}$
}

\begin{abstract}
Wstęp. Rak odbytnicy jest w Polsce jednym z najczęstszych nowotworów, z rosnącą zachorowalnością. Porównania międzynarodowe wskazują na zależność pomiędzy wydatkami na ochronę zdrowia a wskaźnikami 5-letniego przeżycia chorych na nowotwory. W niniejszej pracy, po raz pierwszy w Polsce, przedstawiono analizę związku pomiędzy wskaźnikami 5-letniego przeżycia wśród chorych na raka odbytnicy w poszczególnych województwach a ponoszonymi tam wydatkami na ich leczenie.
\end{abstract}

Materiał i metody. W pracy wykorzystano dane NFZ dostępne w systemie pn. „Rejestr Leczenia Chorób”. Analizie poddano około 25 tysięcy chorych na raka odbytnicy, którzy rozpoczęli leczenie w latach 2005-2008. Wykonano analizę porównawczą wskaźników 5-letniego przeżycia wśród tych osób oraz wydatków ponoszonych w całym cyklu ich leczenia z podziałem na poszczególne województwa.

Wyniki. Wskaźniki 5-letniego przeżycia chorych na raka odbytnicy w Polsce w latach 2005-2008 utrzymywały się na podobnym poziomie (około $41 \%$ u mężczyzn i około 45\% u kobiet), przy względnie dużej różnicy w poszczególnych latach na poziomie województw (w granicach od 36\% do 45\% u mężczyzn i od 39\% do 49\% u kobiet). Stwierdzono także znaczne różnice pomiędzy województwami w wysokości wydatków na leczenie; wśród mężczyzn wynosiły one za cały cykl leczenia od 32,3 do 41,0 tys. PLN na osobę, a u kobiet od 27,0 do 33,3 tys. W większości porównań nie wykazano związku pomiędzy średnią wysokością wydatków na leczenie a wskaźnikami 5-letnich przeżyć.

Wnioski. Przedstawiona analiza wskazuje na brak zależności pomiędzy średnimi wydatkami i wynikami leczenia chorych na raka odbytnicy w Polsce. Przyczyny różnic w wynikach leczenia mogą być zatem zależne od innych czynników, np. stadium klinicznego nowotworu w chwili rozpoczęcia leczenia lub odmiennych sposobów leczenia. Pogłębienie tej analizy z uwzględnieniem przyczyn może się przyczynić do zmniejszenia regionalnych różnic w opiece zdrowotnej i nierówności w uzyskanych wynikach leczenia raka odbytnicy w Polsce.

\section{Effectiveness and costs of rectal cancer therapy in Poland; a regional approach}

Introduction. Rectal cancer is one of the most common malignancies in Poland and is increasing in incidence. International comparisons indicate a positive correlation between health expenditures and 5-year cancer survival rates. This study, for the first time in Poland, correlates 5-year survival rates with expenditures on rectal cancer therapy in various regions of Poland.

\author{
${ }^{1}$ JASPERS \\ Europejski Bank Inwestycyjny, Warszawa* \\ ${ }^{2}$ Zakład Epidemiologii \\ Instytut Zdrowia Publicznego, Collegium Medicum, Uniwersytet Jagielloński w Krakowie \\ ${ }^{3}$ Katedra i Klinika Onkologii i Radioterapii \\ Gdański Uniwersytet Medyczny, Gdańsk \\ ${ }^{4}$ dane-i-analizy.pl sp. z o.o., Kraków \\ ${ }^{5}$ Narodowy Fundusz Zdrowia
}

*Opinie wyrażone przez autora w niniejszym materiale mają charakter osobisty i mogą nie odzwierciedlać stanowiska Europejskiego Banku Inwestycyjnego 
Materials and methods. This study is based on the National Health Fund (NHF) data, available in the Diseases'Treatment Register system. The analysis included approximately 25,000 patients who started their treatment between 2005 and 2008. We analysed 5-year survival rates among these patients versus average expenditures of the NHF on their treatment in particular regions.

Results. Observed 5-year survival rates between 2005 and 2008 were at a similar level (some $41 \%$ and $45 \%$ in men and women, respectively), with relatively large differences between regions (36\% to $45 \%$ in men and $39 \%$ to $49 \%$ in women). The NHF expenditures in the various regions differed significantly. The average costs of an entire treatment cycle per person ranged from 32,300 PLN to 41,000 PLN in both men and women. For comparisons studied no association was found between mean expenditure for treatment and 5-year survival rates.

Conclusions. Survival of rectal cancer patients in various regions does not correlate with the average expenditures on their treatment. The differences in survival rates between the Polish regions will be due to other factors, such as tumour stage at presentation or treatment patterns in the regions. A more thorough analysis of this may aid in decreasing regional discrepancies in care and inequalities in survival rates in rectal cancer patients.

NOWOTWORY Journal of Oncology 2015; 65, 4: 271-280

Słowa kluczowe: rak odbytnicy, przeżycia 5-letnie, koszty leczenia, nierówności w zdrowiu

Key words: rectal cancer, 5-year survival rate, health expenditures, health inequalities

\section{Wstęp}

Poprawa skuteczności klinicznej (efficacy) stanowi centrum zainteresowań klinicystów i naukowców zajmujących się rozwojem metod leczenia. Ekonomiści oraz politycy zdrowotni zwracają z kolei uwagę na efektywność (effectiveness), w szczególności efektywność kosztową interwencji [1]. Najczęściej stosowanym miernikiem skuteczności (performance) systemu opieki zdrowotnej w zakresie opieki onkologicznej jest odsetek 5-letniego przeżycia [2, 3]. Udział 5-letnich przeżyć chorych na raka odbytnicy jest w Polsce niższy niż w większości krajów europejskich i wynosi 44,3\%, podczas gdy w Europie — średnio 55,8\% [4].

Wyniki leczenia raka odbytnicy zależne są przede wszystkim od stopnia zaawansowania nowotworu [5-7]. Udziały 5-letnich przeżyć wśród chorych z rozpoznaniem raka odbytnicy w latach 2004-2010 w USA wahały się od $87 \%$ w I stopniu zaawansowania do $12 \%$ w stopniu IV [8]. Główną metodą leczenia tego nowotworu pozostaje zabieg operacyjny, który u chorych w I stopniu zaawansowania pozwala na uzyskanie ponad 80\% 5-letnich przeżyć. Istotne znaczenie ma technika operacyjna [9], doświadczenie i umiejętności chirurgów [10]. W wyższych stopniach zaawansowania konieczne jest stosowanie leczenia skojarzonego. Zastosowanie przedoperacyjnej radiochemioterapii zmniejsza ryzyko nawrotów choroby i wiąże się z mniejszą liczbą powikłań niż leczenie pooperacyjne [11-13]. Pooperacyjna chemioterapia nie wydłuża czasu przeżycia chorych na raka odbytnicy, którzy otrzymali przed operacją radioterapię i chemioterapię, i nie jest zalecana [14-16].

Koszty leczenia raka odbytnicy w poszczególnych krajach są bardzo zróżnicowane i silnie związane z zaawansowaniem nowotworu $[17,18]$.
W niniejszym opracowaniu przedstawiono wskaźniki przeżycia i wydatki na leczenie chorych na raka odbytnicy w Polsce z uwzględnieniem międzywojewódzkich różnic. Analizę tę przeprowadzono przy użyciu metody zastosowanej wcześniej w odniesieniu do raka piersi w Polsce [19]. Analizie poddano wskaźniki 5-letniego przeżycia chorych, którzy rozpoczęli leczenie w latach 2005-2008. Wydatki, które brano pod uwagę, stanowią koszty bezpośrednie poniesione przez NFZ na wszystkie terapie w okresie od rozpoczęcia leczenia do listopada 2013 roku. W analizie pominięto wydatki NFZ na refundację leków aptecznych oraz wszystkie wydatki ponoszone przez podmioty inne niż NFZ, w tym przez chorych.

\section{Materiał i metody \\ Charakterystyka źródła danych}

NFZ gromadzi dane rozliczeniowe, opisujące charakter i cel wykonania świadczeń realizowanych ze środków publicznych. Zakres tych danych jest określony przez ministra zdrowia w drodze rozporządzenia [20], a z punktu widzenia niniejszej analizy jego najważniejszymi elementami są identyfikatory chorych (w tym PESEL), rozpoznanie kliniczne oznaczone kodem klasyfikacji chorób [21], a także kod, nazwa oraz koszt świadczenia. Przetwarzanie danych odbywa się z wykorzystaniem informatycznego systemu NFZ.

W celu umożliwienia przeprowadzania analiz danych związanych z leczeniem nowotworów w systemie informatycznym Centrali NFZ został stworzony moduł pn. „Rejestr Leczenia Chorób" (RLC). W RLC umieszczone są dane osób, u których rozpoznano nowotwór złośliwy (kody C wg ICD10) lub raka in situ (kody D00-D09 wg ICD10). Jednocześnie osoby te zostały podzielone na te $\mathrm{z}$ podejrzeniem oraz 
z potwierdzeniem rozpoznania nowotworu złośliwego. Za osoby z potwierdzonym rozpoznaniem uznaje się te, które prócz rozpoznania z odpowiednim kodem ICD10 uzyskały świadczenie charakterystyczne dla leczenia nowotworów, takie jak zabieg chirurgiczny, radioterapię, chemioterapię lub leczenie paliatywne. Różnice pomiędzy liczbą osób z podejrzeniem i rozpoznaniem raka jelita grubego przedstawiono we wcześniejszym doniesieniu [22].

System RLC wyposażony jest w interfejs, pozwalający na formułowanie zapytania do bazy danych epizodów leczenia. Dla celów niniejszej analizy korzystano z dwóch z części interfejsu, nazywanych odpowiednio:„Analiza nowotworów — wskaźniki przeżycia” oraz „Analiza nowotworów - podział geograficzny", co umożliwiło uzyskanie danych nt. liczby chorych w bazie NFZ z określonymi cechami oraz kwoty wydatków poniesionych przez NFZ na leczenie tej grupy chorych.

Wskaźniki przeżycia pochodzące z baz NFZ oznaczają iloraz liczby osób, które przeżyły 5 lat od roku rozpoczęcia leczenia nowotworu w stosunku do wszystkich rozpoczynających leczenie w danym roku i stanowią wskaźniki obserwowane.

Wydatki przypisane do poszczególnych chorych stanowią sumę wydatków NFZ na ich leczenie od pierwszego świadczenia oznaczonego kodem rozpoznania nowotworu do końca pobrania danych z bazy RLC, w tym przypadku do listopada 2013 roku. Jest to zatem suma wszystkich wydatków na leczenie tych osób, które poniesiono zarówno w roku rozpoznania nowotworu, jak i przez wszystkie kolejne lata. Przypisanie wydatków do roku następuje zatem na podstawie roku rozpoczęcia leczenia, co nie oznacza, że wydatki te ponoszono w całości w tym roku.

\section{Metoda badawcza}

Z części „Rejestru Leczenia Chorób” pn. „Analiza nowotworów - wskaźniki przeżycia" uzyskano liczbę mężczyzn i kobiet chorych na raka odbytnicy (C19-C20), którzy rozpoczęli leczenie w latach 2005-2008, w tym liczbę tych chorych, którzy przeżyli 5 lat od pierwszego epizodu leczenia. Z części RLC pn. „Analiza nowotworów - podział geograficzny" uzyskano dane o kwocie wydatków ponoszonych przez NFZ w związku ze świadczeniami oznaczonymi kodami C19-C20, wykonanymi na rzecz tych chorych [22]. W analizie wykorzystano dane o chorych z rozpoznaniem postawionym w czterech kolejnych latach (2005-2008).

Przypisanie chorych do województw oparte było na miejscu ich zamieszkania, a nie na miejscu wykonywania świadczeń czy oddziału wojewódzkiego NFZ, który leczenie opłacał. W znacznej mierze województwo zamieszkania odpowiadało oddziałowi wojewódzkiemu, w którym chorzy byli ubezpieczeni, choć w odniesieniu do niewielkiej części chorych występowały różnice. Podobnie przypisanie wydatków do województw odnosiło się do miejsca zamieszkania chorych w roku rozpoczęcia leczenia, a nie oddziału ubezpieczenia czy też miejsca ponoszenia wydatków (lokalizacji placówek leczących). Zatem niezależnie od tego, w którym województwie leczenie było prowadzone, w całości lub części, chory wraz z całą swoją historią był przypisany do województwa, w którym mieszkał w roku rozpoczęcia leczenia. Uwzględniono sumę wydatków na leczenie analizowanej grupy chorych od początku leczenia do czasu zaczerpnięcia danych (listopad 2013).

W statystycznej analizie opisowej posłużono się średnią wydatków na osobę w całym cyklu leczenia oraz liczbami i odsetkami chorych, którzy przeżyli 5 lat, na poziomie województw. Ocenę zależności przeprowadzono przy użyciu analizy korelacji Spearmanna. Poziom istotności przyjęto przy $\mathrm{p}<0,05$. Całość obliczeń wykonano przy użyciu programów Excel oraz SPSS v. 20.

\section{Wyniki}

Do analizy włączono 24791 chorych, w tym 14590 mężczyzn i 10201 kobiet (tab. I). Spośród około 6 tysięcy chorych rocznie rozpoczynających leczenie z powodu raka odbytnicy w kolejnych latach 2005-2008, po 5 latach żyło 41\% mężczyzn i 45\% kobiet. W ciągu 4 lat odsetek 5-letnich przeżyć obniżył się o około 3\% w skali kraju (tab. II). U mężczyzn z rozpoznaniem raka odbytnicy zdiagnozowanym w 2008 r. odsetek 5-letnich przeżyć był najniższy w woj. opolskim i lubelskim (ok. 34\%), a najwyższy w woj. podkarpackim (choć liczba z roku 2008 znacznie odbiegała od tych z innych lat) i mazowieckim. U kobiet najniższe wskaźniki były obserwowane w woj. opolskim i podlaskim (39\%), a najwyższe w woj. kujawsko-pomorskim (53\%) oraz mazowieckim i dolnośląskim (48\%).

Dynamika zmian wskaźnika przeżyć w latach 2005-2008 w poszczególnych województwach nie była jednorodna (tab. II): u mężczyzn w woj. podkarpackim 5-letnie przeżycia wzrosły o $23 \%$, w łódzkim o $15 \%$, podczas gdy w lubuskim spadły o 30\%, w małopolskim o 19\%, a w wielkopolskim o 14\%. U kobiet największą poprawę odnotowano w woj. kujawsko-pomorskim (o 23\%) i lubelskim (o 15\%). Spadek zanotowano natomiast w woj. wielkopolskim (o 20\%), małopolskim (o 18\%) i podlaskim (o 17\%).

W większości województw zmiany 5-letnich odsetków przeżyć były niewielkie (tab. II), co może być dziełem przypadku, tym bardziej, że wskaźniki fluktuują z roku na rok. Są jednak województwa, w których różnice te są bardziej znaczące, a ich zmiany bardziej systematyczne. Dotyczy to np. woj. lubuskiego, a także, chociaż w mniejszym stopniu, woj. małopolskiego i wielkopolskiego, w których trend spadkowy 5-letnich przeżyć u mężczyzn utrzymywał się przez 4 lata z rzędu. U kobiet stabilną poprawę zanotowano w woj. kujawsko-pomorskim.

Przeżycia 5-letnie zestawiono z wydatkami na leczenie chorych z lat 2005-2008 (tab. III). Średnia wysokość 
Tabela I. Liczba nowych przypadków chorych na raka odbytnicy wg województw i roku pierwszego świadczenia w latach 2005-2008

\begin{tabular}{|c|c|c|c|c|c|c|}
\hline \multirow[t]{2}{*}{ Województwo } & \multicolumn{6}{|c|}{ Mężczyźni } \\
\hline & 2005 & 2006 & 2007 & 2008 & $2008 / 2005$ & Średnio rocznie \\
\hline Dolnośląskie & 287 & 279 & 268 & 273 & 0,95 & 277 \\
\hline Kujawsko-pomorskie & 210 & 216 & 182 & 193 & 0,92 & 200 \\
\hline Lubelskie & 181 & 174 & 204 & 227 & 1,25 & 197 \\
\hline Lubuskie & 103 & 96 & 99 & 109 & 1,06 & 102 \\
\hline Łódzkie & 252 & 265 & 281 & 283 & 1,12 & 270 \\
\hline Małopolskie & 290 & 281 & 266 & 296 & 1,02 & 283 \\
\hline Mazowieckie & 464 & 447 & 426 & 487 & 1,05 & 456 \\
\hline Opolskie & 103 & 93 & 93 & 109 & 1,06 & 100 \\
\hline Podkarpackie & 181 & 186 & 206 & 188 & 1,04 & 190 \\
\hline Podlaskie & 116 & 128 & 127 & 133 & 1,15 & 126 \\
\hline Pomorskie & 198 & 189 & 204 & 192 & 0,97 & 196 \\
\hline Śląskie & 490 & 449 & 507 & 494 & 1,01 & 485 \\
\hline Świętokrzyskie & 133 & 110 & 122 & 134 & 1,01 & 125 \\
\hline Warmińsko-mazurskie & 155 & 135 & 148 & 125 & 0,81 & 141 \\
\hline Wielkopolskie & 331 & 368 & 354 & 322 & 0,97 & 344 \\
\hline Zachodniopomorskie & 151 & 152 & 169 & 156 & 1,03 & 157 \\
\hline Polska & 3645 & 3568 & 3656 & 3721 & 1,02 & 3648 \\
\hline \multirow[t]{2}{*}{ Województwo } & \multicolumn{6}{|c|}{ Kobiety } \\
\hline & 2005 & 2006 & 2007 & 2008 & $2008 / 2004$ & Średnio rocznie \\
\hline Dolnośląskie & 186 & 166 & 187 & 188 & 1,01 & 182 \\
\hline Kujawsko-pomorskie & 146 & 114 & 137 & 134 & 0,92 & 133 \\
\hline Lubelskie & 131 & 133 & 136 & 138 & 1,05 & 135 \\
\hline Lubuskie & 68 & 66 & 91 & 94 & 1,38 & 80 \\
\hline Łódzkie & 218 & 191 & 223 & 203 & 0,93 & 209 \\
\hline Małopolskie & 188 & 192 & 213 & 195 & 1,04 & 197 \\
\hline Mazowieckie & 307 & 326 & 306 & 316 & 1,03 & 314 \\
\hline Opolskie & 69 & 67 & 59 & 67 & 0,97 & 66 \\
\hline Podkarpackie & 123 & 115 & 115 & 124 & 1,01 & 119 \\
\hline Podlaskie & 87 & 92 & 71 & 79 & 0,91 & 82 \\
\hline Pomorskie & 122 & 157 & 149 & 141 & 1,16 & 142 \\
\hline Śląskie & 360 & 287 & 363 & 354 & 0,98 & 341 \\
\hline Świętokrzyskie & 84 & 82 & 90 & 94 & 1,12 & 88 \\
\hline Warmińsko-mazurskie & 122 & 81 & 105 & 116 & 0,95 & 106 \\
\hline Wielkopolskie & 241 & 225 & 250 & 230 & 0,95 & 237 \\
\hline Zachodniopomorskie & 121 & 119 & 132 & 115 & 0,95 & 122 \\
\hline Polska & 2573 & 2413 & 2627 & 2588 & 1,01 & 2550 \\
\hline
\end{tabular}

Źródło: dane-i-analizy.pl, na podstawie RLC NFZ

wydatków na leczenie jednego chorego na raka odbytnicy w całej populacji poddanej analizie z czterech kolejnych lat wynosiła około 36 tys. PLN wśród mężczyzn i 31,2 tys. wśród kobiet. W całym okresie i w poszczególnych latach oraz województwach i grupach wiekowych wydatki u mężczyzn są wyższe o ok. 5 tys. PLN. W ciągu badanych 4 lat wydatki rosły z ok. 27 i 30 tys. odpowiednio dla kobiet i mężczyzn w roku 2005 do ok. 35 i 42 tys. w roku 2008. Oprócz różnicy wydatków w zależności od płci charakterystyczny jest spadek wydatków wraz z wiekiem chorych, przy bardzo wysokich wydatkach we względnie nielicznej grupie wiekowej 30-50 lat, sięgających średnio 60-70 tys. PLN (choć w pojedynczych przypadkach koszty przekraczały 100 tys. PLN) (ryc. 1).

Średnio w całym okresie najwyższe wydatki w grupie mężczyzn ponoszono w województwie zachodniopomor- 
Tabela II. Odsetek 5-letnich przeżyć wg województw rozpoznania

\begin{tabular}{|c|c|c|c|c|c|c|}
\hline \multirow[t]{2}{*}{ Województwo } & \multicolumn{6}{|c|}{ Mężczyźni } \\
\hline & 2005 & 2006 & 2007 & 2008 & Zmiana 2008 do 2005 & Średnio za okres \\
\hline Dolnośląskie & $43 \%$ & $41 \%$ & $46 \%$ & $40 \%$ & $93 \%$ & $42 \%$ \\
\hline Kujawsko-pomorskie & $40 \%$ & $39 \%$ & $39 \%$ & $36 \%$ & $90 \%$ & $38 \%$ \\
\hline Lubelskie & $39 \%$ & $43 \%$ & $40 \%$ & $34 \%$ & $89 \%$ & $39 \%$ \\
\hline Lubuskie & $41 \%$ & $38 \%$ & $37 \%$ & $28 \%$ & $70 \%$ & $36 \%$ \\
\hline Łódzkie & $34 \%$ & $36 \%$ & $39 \%$ & $39 \%$ & $115 \%$ & $37 \%$ \\
\hline Małopolskie & $46 \%$ & $44 \%$ & $39 \%$ & $37 \%$ & $81 \%$ & $41 \%$ \\
\hline Mazowieckie & $42 \%$ & $49 \%$ & $46 \%$ & $43 \%$ & $102 \%$ & $45 \%$ \\
\hline Opolskie & $33 \%$ & $37 \%$ & $39 \%$ & $34 \%$ & $103 \%$ & $36 \%$ \\
\hline Podkarpackie & $40 \%$ & $45 \%$ & $39 \%$ & $49 \%$ & $123 \%$ & $43 \%$ \\
\hline Podlaskie & $34 \%$ & $39 \%$ & $42 \%$ & $37 \%$ & $110 \%$ & $38 \%$ \\
\hline Pomorskie & $42 \%$ & $43 \%$ & $44 \%$ & $42 \%$ & $98 \%$ & $43 \%$ \\
\hline Śląskie & $39 \%$ & $39 \%$ & $40 \%$ & $38 \%$ & $99 \%$ & $39 \%$ \\
\hline Świętokrzyskie & $39 \%$ & $37 \%$ & $39 \%$ & $42 \%$ & $107 \%$ & $39 \%$ \\
\hline Warmińsko-mazurskie & $37 \%$ & $45 \%$ & $43 \%$ & $38 \%$ & $100 \%$ & $41 \%$ \\
\hline Wielkopolskie & $47 \%$ & $44 \%$ & $40 \%$ & $40 \%$ & $86 \%$ & $43 \%$ \\
\hline Zachodniopomorskie & $38 \%$ & $36 \%$ & $46 \%$ & $42 \%$ & $112 \%$ & $40 \%$ \\
\hline Polska & $40 \%$ & $42 \%$ & $41 \%$ & $39 \%$ & $97 \%$ & $41 \%$ \\
\hline \multirow[t]{2}{*}{ Województwo } & \multicolumn{6}{|c|}{ Kobiety } \\
\hline & 2005 & 2006 & 2007 & 2008 & Zmiana 2008 do 2005 & Średnio za okres \\
\hline Dolnośląskie & $44 \%$ & $37 \%$ & $51 \%$ & $48 \%$ & $109 \%$ & $45 \%$ \\
\hline Kujawsko-pomorskie & $43 \%$ & $47 \%$ & $49 \%$ & $53 \%$ & $123 \%$ & $48 \%$ \\
\hline Lubelskie & $37 \%$ & $48 \%$ & $45 \%$ & $42 \%$ & $115 \%$ & $43 \%$ \\
\hline Lubuskie & $43 \%$ & $39 \%$ & $49 \%$ & $44 \%$ & $102 \%$ & $44 \%$ \\
\hline Łódzkie & $44 \%$ & $41 \%$ & $39 \%$ & $45 \%$ & $103 \%$ & $42 \%$ \\
\hline Małopolskie & $50 \%$ & $44 \%$ & $49 \%$ & $41 \%$ & $82 \%$ & $46 \%$ \\
\hline Mazowieckie & $49 \%$ & $47 \%$ & $50 \%$ & $48 \%$ & $99 \%$ & $49 \%$ \\
\hline Opolskie & $46 \%$ & $43 \%$ & $29 \%$ & $39 \%$ & $84 \%$ & $39 \%$ \\
\hline Podkarpackie & $50 \%$ & $50 \%$ & $41 \%$ & $45 \%$ & $90 \%$ & $47 \%$ \\
\hline Podlaskie & $47 \%$ & $45 \%$ & $44 \%$ & $39 \%$ & $83 \%$ & $44 \%$ \\
\hline Pomorskie & $48 \%$ & $41 \%$ & $48 \%$ & $47 \%$ & $97 \%$ & $46 \%$ \\
\hline Śląskie & $40 \%$ & $47 \%$ & $45 \%$ & $43 \%$ & $107 \%$ & $44 \%$ \\
\hline Świętokrzyskie & $43 \%$ & $46 \%$ & $38 \%$ & $40 \%$ & $94 \%$ & $42 \%$ \\
\hline Warmińsko-mazurskie & $48 \%$ & $44 \%$ & $44 \%$ & $43 \%$ & $91 \%$ & $45 \%$ \\
\hline Wielkopolskie & $56 \%$ & $38 \%$ & $45 \%$ & $44 \%$ & $80 \%$ & $46 \%$ \\
\hline Zachodniopomorskie & $50 \%$ & $45 \%$ & $51 \%$ & $45 \%$ & $91 \%$ & $48 \%$ \\
\hline Polska & $46 \%$ & $44 \%$ & $46 \%$ & $45 \%$ & $97 \%$ & $45 \%$ \\
\hline
\end{tabular}

Źródło: dane-i-analizy.pl, na podstawie RLC NFZ

skim (41 tys. PLN/osobę), najniższe zaś w woj. dolnośląskim i pomorskim (ok. 32 tys. PLN/osobę). U mężczyzn z rozpoznaniem z roku 2008 najwyższe wydatki ponoszono w woj. podkarpackim (ok. 50 tys. PLN/osobę), najniższe zaś w woj. warmińsko-mazurskim i wielkopolskim (ok. 34 tys. PLN/osobę). U kobiet różnice międzywojewódzkie były nieco mniejsze; najwyższe notowano w woj. warmińsko-mazurskim, lu- belskim oraz podlaskim (po ok. 39 tys. PLN/osobę), najniższe zaś w woj. łódzkim (ok. 27 tys. PLN/osobę).

Nie wykazano zależności na poziomie międzywojewódzkim pomiędzy wskaźnikiem 5-letnich przeżyć a średnimi wydatkami na osobę łącznie za lata 2005-2008. Oznacza to, że różnic we wskaźnikach przeżycia nie udało się wytłumaczyć różnicami w kwocie wydatków na leczenie; 
Tabela III. Średnie wydatki NFZ na leczenie u chorych na raka odbytnicy z rozpoznaniem w kolejnych latach 2005-2008 wg województw i płci, w tysiącach złotych

\begin{tabular}{|c|c|c|c|c|c|c|}
\hline \multirow[t]{2}{*}{ Województwo } & \multicolumn{6}{|c|}{ Mężczyźni } \\
\hline & 2005 & 2006 & 2007 & 2008 & $2008 / 2005$ & Średnio $2005-2008$ \\
\hline Dolnośląskie & 27054 & 29994 & 34915 & 37436 & 1,38 & 32350 \\
\hline Kujawsko-pomorskie & 28858 & 27339 & 37174 & 43218 & 1,50 & 34147 \\
\hline Lubelskie & 36057 & 34342 & 42446 & 45795 & 1,27 & 39660 \\
\hline Lubuskie & 26745 & 36248 & 36246 & 42172 & 1,58 & 35353 \\
\hline Łódzkie & 28152 & 31788 & 31579 & 39915 & 1,42 & 32858 \\
\hline Małopolskie & 30545 & 38561 & 38249 & 42222 & 1,38 & 37394 \\
\hline Mazowieckie & 35578 & 35465 & 37906 & 43651 & 1,23 & 38150 \\
\hline Opolskie & 26894 & 36842 & 36241 & 36324 & 1,35 & 34075 \\
\hline Podkarpackie & 29366 & 32699 & 36334 & 50522 & 1,72 & 37230 \\
\hline Podlaskie & 30626 & 35431 & 41419 & 49817 & 1,63 & 39323 \\
\hline Pomorskie & 25822 & 34629 & 30535 & 39116 & 1,51 & 32525 \\
\hline Śląskie & 29639 & 33971 & 40537 & 41033 & 1,38 & 36295 \\
\hline Świętokrzyskie & 33597 & 34723 & 37790 & 41746 & 1,24 & 36964 \\
\hline Warmińsko-mazurskie & 26238 & 40458 & 38559 & 33108 & 1,26 & 34591 \\
\hline Wielkopolskie & 31109 & 33192 & 34358 & 39573 & 1,27 & 34558 \\
\hline Zachodniopomorskie & 37253 & 38994 & 41115 & 46727 & 1,25 & 41022 \\
\hline Polska & 30534 & 34223 & 37169 & 41987 & 1,38 & 35978 \\
\hline \multirow[t]{2}{*}{ Województwo } & \multicolumn{6}{|c|}{ Kobiety } \\
\hline & 2005 & 2006 & 2007 & 2008 & $2008 / 2005$ & Średnio 2005-2008 \\
\hline Dolnośląskie & 24984 & 30219 & 36737 & 37307 & 1,49 & 32311 \\
\hline Kujawsko-pomorskie & 23737 & 28546 & 27527 & 31118 & 1,31 & 27732 \\
\hline Lubelskie & 25289 & 31931 & 36,576 & 39579 & 1,57 & 33344 \\
\hline Lubuskie & 24369 & 25750 & 30081 & 37277 & 1,53 & 29369 \\
\hline Łódzkie & 26227 & 26256 & 29120 & 26645 & 1,02 & 27062 \\
\hline Małopolskie & 28084 & 29389 & 33366 & 33955 & 1,21 & 31199 \\
\hline Mazowieckie & 29406 & 31539 & 34759 & 33817 & 1,15 & 32380 \\
\hline Opolskie & 29102 & 26098 & 38802 & 32374 & 1,11 & 31594 \\
\hline Podkarpackie & 25912 & 30435 & 35649 & 37108 & 1,43 & 32276 \\
\hline Podlaskie & 27372 & 33348 & 27228 & 38914 & 1,42 & 31715 \\
\hline Pomorskie & 21263 & 28049 & 31359 & 36008 & 1,69 & 29170 \\
\hline Śląskie & 26903 & 28584 & 31345 & 38159 & 1,42 & 31248 \\
\hline Świętokrzyskie & 28056 & 27448 & 37935 & 37816 & 1,35 & 32814 \\
\hline Warmińsko-mazurskie & 30054 & 27014 & 38493 & 39181 & 1,30 & 33686 \\
\hline Wielkopolskie & 30330 & 30205 & 32058 & 36614 & 1,21 & 32302 \\
\hline Zachodniopomorskie & 33297 & 31921 & 29517 & 30842 & 0,93 & 31394 \\
\hline Polska & 27332 & 29471 & 32862 & 35303 & 1,29 & 31242 \\
\hline
\end{tabular}

Źródło: dane-i-analizy.pl, na podstawie RLC NFZ

współczynnik korelacji u mężczyzn wynosił-0,069, a u kobiet -0,147 (w obu wypadkach nieznamienna zależność) (ryc. 2).

W analogicznej analizie wykonanej dla poszczególnych lat obserwacji również nie stwierdzono zależności ww. zmiennych, a współczynnik korelacji był niestabilny i zmieniał się, przyjmując wartości ujemne i dodatnie. W 2005 roku wynosił 0,042 u mężczyzn (różnica nieznamienna) oraz
0,517 u kobiet $(p<0,05)$, natomiast w 2008 roku wynosił -0,466 u mężczyzn, a u kobiet 0,157 (w obu przypadkach różnica nieznamienna).

Wydatki w poszczególnych województwach w kolejnych latach ulegały pewnym zmianom. U kobiet charakterystyczne są niskie wydatki (przy średnich wskaźnikach przeżycia) w województwie łódzkim oraz umiarkowanie 


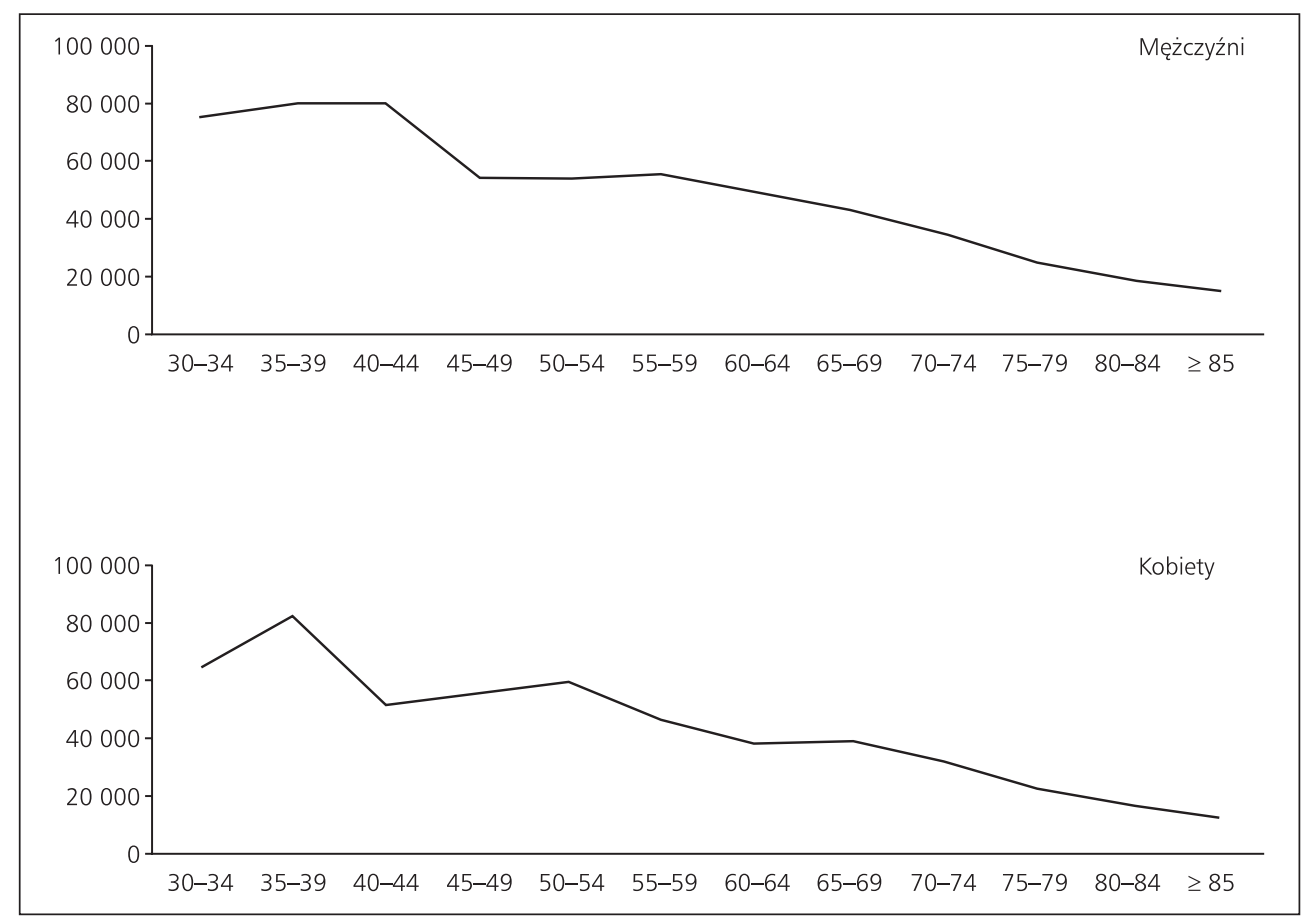

Rycina 1. Wykres wydatków NFZ na leczenie chorych na raka odbytnicy, rozpoczynających leczenie w roku 2008, w grupach wieku w momencie rozpoznania, mężczyźni i kobiety. Źródło: Rejestr Leczenia Chorób, NFZ

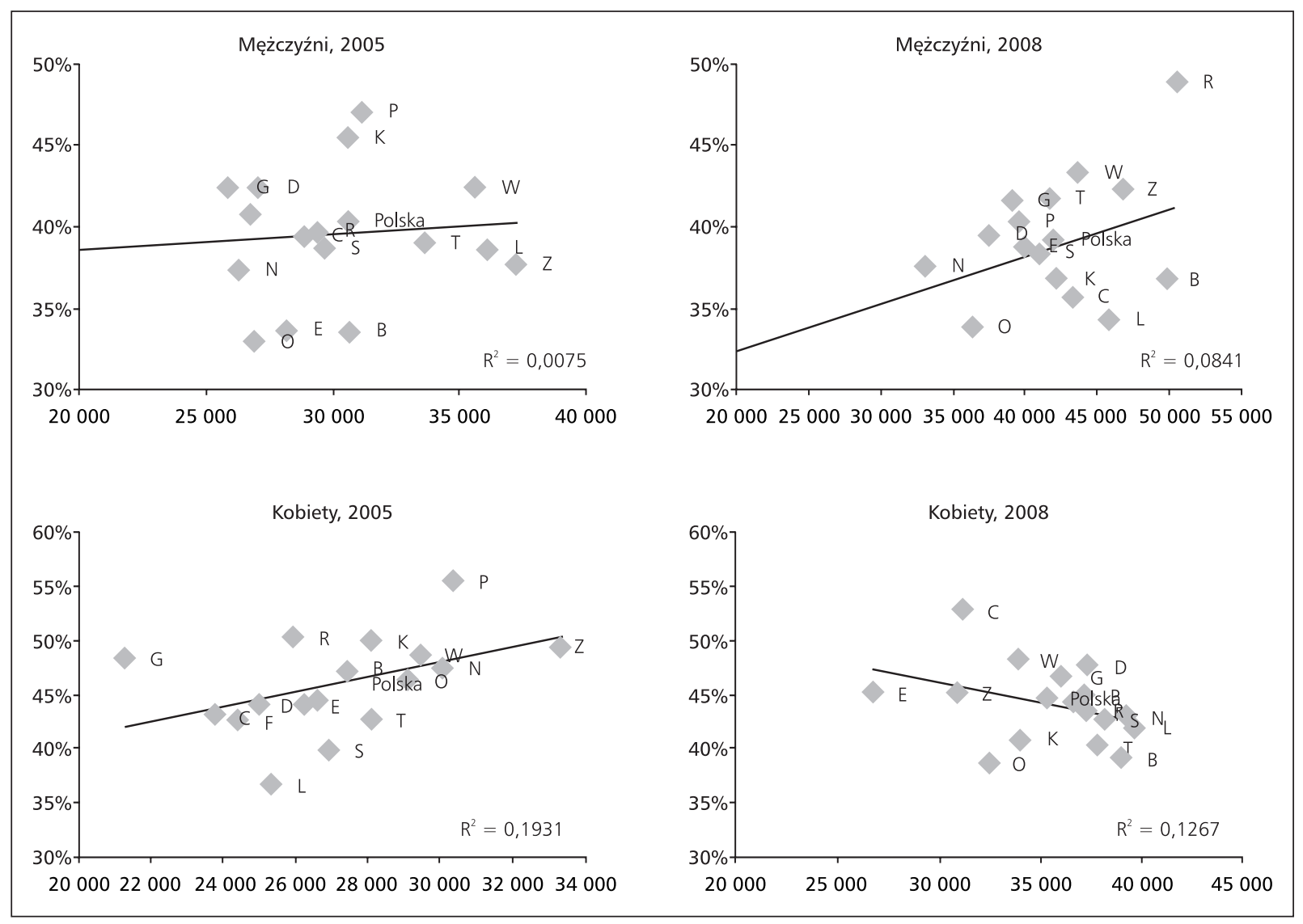

Rycina 2. Wykres zależności pomiędzy wydatkami na leczenie raka odbytnicy a odsetkiem przeżyć 5-letnich u mężczyzn i kobiet z rozpoznaniem w latach 2005 i 2008, wg województw. Źródło: dane-i-analizy.pl, na podstawie RLC NFZ. Oznaczenie województw: D — dolnośląskie,

C - kujawsko--pomorskie, L - lubelskie, F- lubuskie, E - łódzkie, $\mathrm{K}$ - małopolskie, $\mathrm{W}$ - mazowieckie, $\mathrm{O}$ - opolskie, $\mathrm{R}$ - podkarpackie, $\mathrm{B}$ - podlaskie, $\mathrm{G}$ - pomorskie, $\mathrm{S}$ - śląskie, $\mathrm{T}$ - świętokrzyskie, $\mathrm{N}$ - warmińsko-mazurskie, $\mathrm{P}$ - wielkopolskie, $\mathrm{Z}$ — zachodniopomorskie 


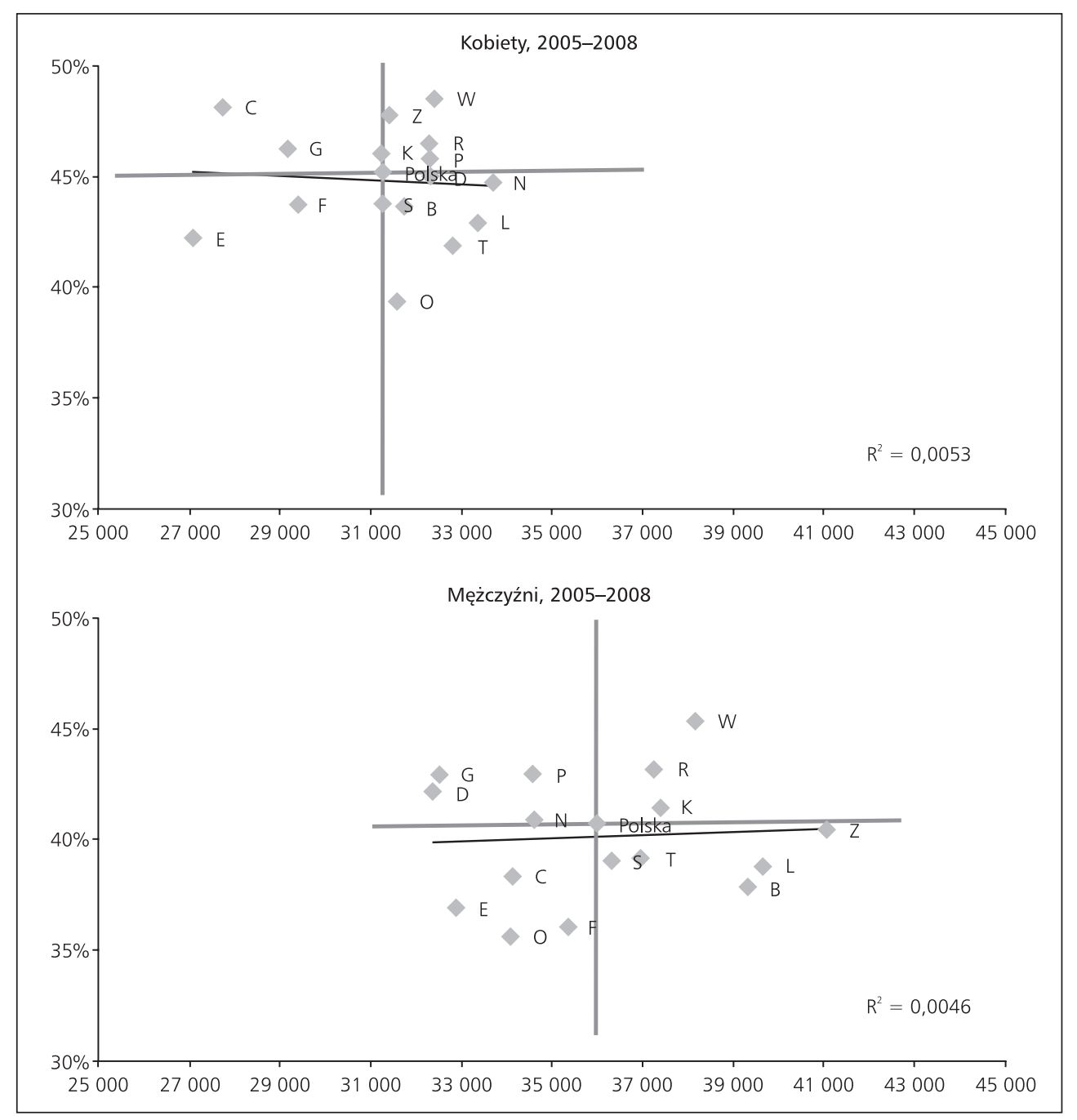

Rycina 3. Zależności pomiędzy średnimi wydatkami na leczenie raka odbytnicy a odsetkiem 5-letnich przeżyć u chorych z rozpoznaniem w latach 2005-2008, wg województw. Źródło: dane-i-analizy.pl, na podstawie RLC NFZ

wysokie wydatki i stabilnie dość dobre wskaźniki przeżycia w wojewódzkie mazowieckim. Z kolei u mężczyzn zwracają uwagę bardzo niskie wskaźniki przeżycia w województwie opolskim, przy średnim poziomie wydatków.

Linia korelacji pomiędzy średnimi wartościami wydatków oraz 5-letnich przeżyć wśród chorych, którzy rozpoczęli leczenie w latach 2005-2008, jest prawie idealnie płaska dla obu płci (ryc. 2). Wskazuje to, iż wysokość nakładów na leczenie nie miała związku z jego odległym efektem. Województwa można podzielić na cztery grupy (ryc. 3): takie, w których przy wysokim wskaźniku 5-letnich przeżyć (powyżej średniej krajowej) wydatki na leczenie były względnie niskie (np. u kobiet w woj. kujawsko-pomorskim i pomorskim, a u mężczyzn w woj. pomorskim, dolnośląskim czy wielkopolskim), oraz takie, w których wydatki były względnie wysokie (np. u obu płci w woj. mazowieckim i podkarpackim). Z drugiej strony w grupie województw, w których odsetek przeżyć 5-letnich był względnie niski (poniżej średniej), były takie, w których wydatki były wysokie (u kobiet woj. opolskie, świętokrzyskie i lubelskie, u mężczyzn woj. lubelskie i podlaskie) lub niskie (u kobiet woj. łódzkie i lubuskie, u mężczyzn woj. łódzkie, opolskie i kujawsko-pomorskie).

\section{Dyskusja}

W przedstawionym badaniu analizie poddano wskaźniki 5-letnich przeżyć w populacji chorych, u których rozpoznano raka odbytnicy w latach 2005-2008 oraz wydatki na leczenie tych chorych ponoszone przez NFZ od początku leczenia do listopada 2013 roku. W okresie 2005-2008 odsetek 5-letnich przeżyć w całej Polsce obniżył się o około 3\% i wynosił 41\% u mężczyzn i 45\% u kobiet. Względne wskaźniki 5-letnich przeżyć (relative survival rate, RSR) z danych Krajowego Rejestru Nowotworów, obejmujące chorych, którzy rozpoczęli leczenie w latach 2003-2005, szacowane są na $46,9 \%$ u mężczyzn i $48,8 \%$ u kobiet $[23,24]$. 
Wskaźniki 5-letnich przeżyć wylicza się na podstawie danych poszczególnych osób, w tym wieku rozpoznania, płci i wieku w chwili zgonu. Dla zapewnienia lepszej porównywalności wyników dokonywana jest standaryzacja względem prawdopodobieństwa zgonu w ogólnej populacji (relative survival rate - RSR). W niniejszym materiale zastosowano podejście wynikające z natury źródła danych. Wskaźniki przeżycia pochodzące z baz NFZ, tzw. wskaźniki obserwowane, aczkolwiek nazywane wskaźnikami 5-letniego przeżycia, nie są porównywalne ze wskaźnikami o tej samej nazwie publikowanymi przez Krajowy Rejestr Nowotworów lub organizacje międzynarodowe. Nie zostały one także skorygowane o różnice w prawdopodobieństwie zgonu w ogólnej populacji, które mogły wystąpić pomiędzy województwami oraz w poszczególnych latach obserwacji, ani o różnice wieku populacji w tych województwach. Nie dokonano także korekty na „siłę nabywczą" wydatków. Nieuwzględnienie tych zmiennych w pewnym stopniu mogło wpłynąć na wyniki, lecz siła ich wpływu jest najpewniej niewielka. W pewnym stopniu zaburzeniem we wnioskowaniu może być także migracja pacjentów między województwami, która częściowo niweluje różnice w zakresie wyposażenia, dostępu do kadr, i w rezultacie efektów samego leczenia (w tym satysfakcji z tegoż).

Pomimo tych ograniczeń analiza pozwala uznać, że nie ma związku pomiędzy wydatkami na leczenie a osiąganymi wynikami tego leczenia w poszczególnych województwach. Linia zależności jest na ogół niemal równoległa lub nawet odwrotna (choć nieistotna statystycznie), tzn. przeżycia 5-letnie były niższe w województwach z wyższymi wydatkami. Podobny brak zależności pomiędzy skutecznością leczenia a jego kosztami wykazaliśmy wcześniej w odniesieniu do raka piersi [19]. Możliwe są różne zależności pomiędzy kosztami leczenia a jego skutecznością. Większe nakłady na leczenie mogą się wiązać z jego większą skutecznością, jednak z drugiej strony niska skuteczność leczenia może wymuszać ponoszenie wyższych kosztów, np. ze względu na występowanie nawrotów choroby. W niniejszej analizie nie było możliwe wskazanie przyczyn opisanej zależności.

Różnice w przeżyciach 5-letnich wśród chorych w różnych województwach były znaczne i sięgały 10 punktów procentowych. Amplituda zmiany wysokości wskaźnika 5-letnich przeżyć z roku na rok sugeruje pewną przypadkowość tych wyników, a nie stabilne trendy czy tendencje. Jednak w niektórych województwach istnieją tendencje, które wydają się bardziej stabilne, co najmniej z perspektywy tej krótkiej obserwacji.

Wydatki na leczenie chorych na raka odbytnicy przedstawiono w ujęciu wieloletnim, począwszy od roku rozpoznania do końca obserwacji (listopad 2013). Analiza tych wielkości wykazuje stopniowy wzrost wydatków w latach 2005-2008, z około 27 tys. u kobiet i 30,5 tys. u mężczyzn do 35 tys. PLN u kobiet i 42 tys. u mężczyzn. W sumie wy- datki na leczenie tej grupy chorych wzrosły w kolejnych latach o około $40 \%$ u mężczyzn i o 30\% u kobiet. Różnice międzywojewódzkie w wydatkach na leczenie chorych na raka odbytnicy były mniejsze niż podobne różnice wśród chorych na raka piersi, opisywane w naszych poprzednich doniesieniach [25].

Istnieje kilka elementów, które mogą tłumaczyć otrzymane wyniki i które ograniczały możliwość wnioskowania. W analizie nie uwzględniono stadium klinicznego zaawansowania nowotworu, co z pewnością miało wpływ na skuteczność leczenia i jego koszty. Bardziej zaawansowany nowotwór może powodować konieczność większych nakładów, np. koszty ponoszone w Niemczech na leczenie raka jelita grubego i odbytnicy w zaawansowanych stadiach choroby były około dwukrotnie wyższe w porównaniu z leczeniem nowotworu we wcześniejszych stadiach [26]. Jednocześnie wcześniejszy zgon z powodu zaawansowania choroby może zmniejszać wydatki ponoszone na leczenie, co przy wysokiej śmiertelności w Polsce (ok. $60 \%$ w ciągu 5 lat) może mieć znaczenie.

Przeżycia 5-letnie w chorobach nowotworowych zależą od wielu czynników, wśród których poziom wydatków w opracowaniach międzynarodowych uznaje się za jeden $z$ istotniejszych [27, 28]. W obecnej analizie, opartej na rzeczywistych danych obejmujących duże grupy chorych na raka odbytnicy w Polsce, nie udało się jednak wykazać takiej zależności w analizie wg województw. Zjawisko to może sugerować, że część środków wydatkowanych na opiekę onkologiczną przeznaczana jest na świadczenia, które nie mają wpływu na wyniki leczenia, lub że świadczenia są stosowane w nieodpowiedniej grupie chorych, np. wykorzystywanie kosztownych radykalnych procedur w zaawansowanym stadium choroby. Może to mieć miejsce np. w przypadku niedokładnej oceny stopnia zaawansowania lub zbyt długiego czasu oczekiwania na rozpoczęcie pierwszego lub kolejnych etapów leczenia.

Wydatki na leczenie raka odbytnicy w Polsce wzrosły w ostatnich latach, podobnie jak w innych krajach, jednak wyniki tego leczenia w Polsce są nadal gorsze niż średnia w krajach Unii Europejskiej i USA. Dokładne wyjaśnienie przyczyn takich wyników leczenia raka odbytnicy w Polsce wymaga analiz uwzględniających stopnie zaawansowania oraz stosowane metody leczenia, co może się przyczynić do zmniejszenia regionalnych różnic w opiece zdrowotnej i nierówności w uzyskanych wynikach leczenia.

\section{Konflikt interesów: nie zgłoszono}

\section{Dr n. med. Adam Kozierkiewicz}

ul. Drawska 14b/3, 02-202 Warszawa

e-mail:akozierkiewicz@wp.pl

Otrzymano: 30 marca 2015 r

Przyjęto do druku: 2 czerwca 2015 r. 


\section{Piśmiennictwo}

1. Drummond MF, O'Brien BJ, Stoddart GL i wsp. Methods for the economic evaluation of health care programmes. 2nd ed. Oxford, New York, Toronto: Oxford University Press, 1997.

2. AlHW. National Health Performance Framework. Australian Institute of Health and Welfare. http://meteor.aihw.gov.au/content/index. phtml/itemld/392569.

3. Smith PC, Mossialos E, Papanicolas I i wsp. Performance measurement for health system improvement. Cambridge: Cambridge University Press, 2009.

4. De Angelis R, Sant M, Coleman MP i wsp. Cancer survival in Europe 1999-2007 by country and age: results of EUROCARE-5 — a population-based study. Lancet Oncol 2014; 15: 23-34.

5. Forbes LJ, Warburton F, Richards MA i wsp. Risk factors for delay in symptomatic presentation: a survey of cancer patients. Br J Cancer 2014; 111: 581-588.

6. Lim SB, Yu CS, Jang SJ i wsp. Prognostic significance of lymphovascular invasion in sporadic colorectal cancer. Dis Colon Rectum 2010; 53:377-384.

7. Szynglarewicz B, Matkowski R, Smorąg Z i wsp. Rak odbytnicy u mężczyzn: czynniki wpływające na przeżycia całkowite po przedniej resekcji metodą całkowitego wycięcia mezorektum. Przegl Gastroenterol 2007; 2: 125-129.

8. Chen VW, Hsieh MC, Charlton ME i wsp. Analysis of stage and clini$\mathrm{cal} /$ prognostic factors for colon and rectal cancer from SEER registries: AJCC and collaborative stage data collection system. Cancer 2014; 120 (supl. 23): 3793-3806.

9. Bujko K. Leczenie chorych na raka odbytnicy. Gastroenterol Klin 2011; 3: 65-71.

10. Rogers SO Jr, Wolf RE, Zaslavsky AM i wsp. Relation of surgeon and hospital volume to processes and outcomes of colorectal cancer surgery. Ann Surg 2006; 244: 1003-1011.

11. Folkesson J, Birgisson H, Pahlman L i wsp. Swedish Rectal Cancer Trial: long lasting benefits from radiotherapy on survival and local recurrence rate. J Clin Oncol 2005; 23: 5644-5650.

12. Swedish Rectal Cancer Trial. Improved survival with preoperative radiotherapy in resectable rectal cancer. N Engl J Med 1997; 336: 1539.

13. Bujko K, Nowacki MP, Nasierowska-Guttmejer A i wsp. Long-term results of randomized trial comparing preoperative short-course radiotherapy with preoperative conventionally fractionated chemoradiation for rectal cancer. Br J Surg 2006; 93: 1215-1223.

14. Breugom AJ, van Gijn W, Muller EW i wsp. Adjuvant chemotherapy for rectal cancer patients treated with preoperative (chemo)radiotherapy and total mesorectal excision: a Dutch Colorectal Cancer Group (DCCG) randomized phase III trial. Ann Oncol 2015; 26: 696-701.

15. Williamson JS, Jones HG, Davies M i wsp. Outcomes in locally advanced rectal cancer with highly selective preoperative chemoradiotherapy. Br J Surg 2014; 101: 1290-1298.

16. Bujko K, Glynne-Jones R, Bujko M. Does adjuvant fluoropyrimidine-based chemoptherapy provide a benefit for patients with resected rectal cancer who have received neoadjuvant radiochemotherapy? A systematic review of randomised trials. Ann Oncol 2010; 21: 1743-1750.

17. Yabroff KR, Warren JL, Schrag D i wsp. Comparison of approaches for estimating incidence costs of care for colorectal cancer patients. Med Care 2009; 47 (supl. 1): S56-S63.

18. Lang $\mathrm{K}$, Lines LM, Lee DW i wsp. Lifetime and treatment-phase costs associated with colorectal cancer: evidence from SEER-Medicare data. Clin Gastroenterol Hepatol 2009; 7: 198-204.

19. Kozierkiewicz A, Topór-Mądry R, Śliwczyński A i wsp. Skuteczność i koszty leczenia raka piersi w Polsce; podejście regionalne. Nowotwory J Oncol 2014; 64: 24-32.

20. Rozporządzenie ministra zdrowia, z dnia 27 czerwca 2006 r. w sprawie zakresu niezbędnych informacji gromadzonych przez świadczeniodawców (...). Dz.U.06.114.780.

21. World Health Organization. Międzynarodowa Statystyczna Klasyfikacja Chorób i Problemów Zdrowotnych, Rewizja Dziesiąta. Kraków: Fundacja Zdrowia Publicznego, 1992.

22. Didkowska J, Wojciechowska U, Kozierkiewicz A i wsp. Porównanie liczebności zbiorów. Onkol Prakt Klin 2012; 8: 129-142.

23. Wojciechowska U, Didkowska J, Zatoński W. Nowotwory złośliwe w Polsce - wskaźniki 5 letnich przeżyć wg województw. Warszawa: Krajowy Rejestr Nowotworów, 2010.

24. Krajowy Rejestr Nowotworów. Nowotwory złośliwe odbytnicy (C19-20) http://onkologia.org.pl/nowotwory-zlosliwe-odbytnicy-c19-20, data dostępu: 30.06.2014

25. Kozierkiewicz A, Śliwczyński A, Pakulski M i wsp. Wydatki na leczenie raka piersi w Polsce. Nowotwory J Oncol 2013; 64: 217-226.

26. Haug U, Engel S, Verheyen F i wsp. Estimating colorectal cancer treatment costs: a pragmatic approach exemplified by health insurance data from Germany. PLoS One 2014; 9:e88407.

27. OECD. System of Health Accounts. Paryż: OECD, 2001.

28. Kozierkiewicz A, Bochenek T, Gilewski D i wsp. Biała Księga. Zwalczanie raka jelita grubego i raka piersi w Polsce na tle wybranych krajów europejskich. Warszawa-Kraków: Ośrodek Analiz Uniwersyteckich Sp. z o.o., 2011. 